\title{
Pregnancy outcome in women presenting with per vaginal bleeding in first trimester of pregnancy
}

\author{
Aisha Moon*, Saima Shabbir \\ Department of Obstetrics and Gynecology, Kulsumbai Valika Social Security, S. I. T. E. Hospital, Karachi, Pakistan \\ Received: 30 November 2020 \\ Accepted: 07 January 2021

\section{*Correspondence:} \\ Dr. Aisha Moon, \\ E-mail: a.moon_07@hotmail.com \\ Copyright: (C) the author(s), publisher and licensee Medip Academy. This is an open-access article distributed under \\ the terms of the Creative Commons Attribution Non-Commercial License, which permits unrestricted non-commercial \\ use, distribution, and reproduction in any medium, provided the original work is properly cited.
}

\begin{abstract}
Background: Approximately $16 \%-25 \%$ of pregnancies are complicated by first trimester bleeding. The wide range of causes of early pregnancy bleeding, threat to loss the pregnancy and fear of having any life threatening cause puts pregnant female with first trimester bleeding into the state of uncertainty which leads to anxiety and depression. The objective of this study was to determine fetal outcome in women presenting with per vaginal bleeding in first trimester of pregnancy.

Methods: This prospective observational study was carried out on 75 women presenting with complain of first trimester bleeding at Kulsumbai Valika hospital, a tertiary care hospital located in SITE area Karachi, Pakistan from July 2019 to July 2020 for a period of 1 year. A Performa was designed to collect information and patient followed until pregnancy is terminated.

Results: The majority of participants presented at 8th week of gestation. Out of 75 participants who presented with first trimester bleeding $40 \%$ ended up in miscarriage. $6 \%$ had ectopic, $2 \%$ had molar pregnancy, $4 \%$ had placenta previa, $6 \%$ had preterm birth and $40 \%$ had healthy infant at the end of pregnancy.

Conclusions: Bleeding in pregnancy is a red flag sign and needs to be addressed with wise approach to have optimal possible maternal and fetal outcomes.
\end{abstract}

Keywords: Bleeding, Ectopic, First trimester, Molar, Miscarriage, Outcome, Preterm, Previous miscarriage

\section{INTRODUCTION}

Approximately 16\%-25\% of pregnancies are complicated by first trimester bleeding. ${ }^{1-3}$ Bleeding in early pregnancy is a common symptom and its etiologies vary from very benign conditions to life threatening events. Common causes of first trimester bleeding include implantation bleeding, local cause i.e. cervicitis and miscarriages but there could be some life threatening causes as well including ectopic pregnancy and molar pregnancy. Many pregnancies with early pregnancy bleeding continue beyond age of viability and also end in healthy term infant but in some cases it may end up with placenta Previa or prematurity.
Around $20 \%$ of pregnancies end up in miscarriage and $1.1 \%$ have ectopic pregnancy. ${ }^{4}$ Molar pregnancy is a rare cause of early pregnancy bleeding $0.14 \%$, it is more common in Asian population as compared to non-Asians and the incidence in Asian women is $0.2 \% .^{5}$ Although ectopic pregnancy is a less common cause but it is associated with maternal mortality and the mortality rate is $0.2 / 1000 .^{4}$

The chance of having a healthy term infant with first trimester bleeding is stated from $50 \%$ to $75 \%$ in some studies. ${ }^{6,9}$ The wide range of causes of early pregnancy bleeding, threat to loss the pregnancy and fear of having any life threatening cause puts pregnant female with first 
trimester bleeding into the state of uncertainty which leads to great anxiety and depression. ${ }^{7}$

There is uncertainty regarding maternal and fetal outcome in patients with first trimester vaginal bleeding, this uncertainty makes the counselling difficult for doctors who are dealing with the females with condition. Studies addressing this condition and the outcome will help clinicians in counselling. There are few studies done recent past in our country who could address this issue. ${ }^{8}$

The objective of this study was to determine outcome in women presenting with per vaginal bleeding in first trimester of pregnancy. This study will not only help general physicians, emergency department doctors and obstetricians to deal with uncertainty associated with early pregnancy bleeding but will help in counselling as well.

\section{METHODS}

This prospective observational study was carried out on 75 women presenting with complain of first trimester bleeding at Kulsumbai Valika Hospital, a tertiary care hospital located in SITE area Karachi, Pakistan from July 2019 to July 2020 for a period of 1 year. Patients with history of amenorrhea and positive pregnancy test with bleeding per vaginum in first trimester i.e. first 12 weeks of pregnancy.

In this study clinical history was taken followed by gynecological examination of the participants at booking visit. The participants were followed up in antenatal clinic and repeat ultrasound scans were done if required. The design of study is used to study relationship between variables. Independent variable of this study was a history of pervaginal bleeding and dependent variables was pregnancy outcome. A performa was designed to collect information and patient followed until pregnancy is terminated.

\section{Inclusion criteria}

Less than 3 months of amenorrhea, positive urine pregnancy test, bleeding per vaginum in first 12 weeks of pregnancy, no previous history of cervical and vaginal pathology patients were included in the study.

\section{Exclusion criteria}

Participants refused to give consent, all patients presenting beyond 12 weeks of pregnancy, patients with known bleeding tendencies were excluded from the study.

\section{Statistical analysis}

Quantitative variables compared using t-test. Qualitative variables compared using chi-square and fisher exact test. A p-value $<0.05$ was considered statistically significant.
The history of vaginal bleeding was categorized as no. of episodes of vaginal bleeding and divided into 1-3 bleeding episodes, 3-5 bleeding episodes, and more than 5 bleeding episodes. Ultrasound scans were done in all included participants. Patients were followed prospectively and outcomes were studied.

Fetal outcomes were categorized as miscarriage (loss of pregnancy before 24 completed weeks of pregnancy), ectopic pregnancy (pregnancy outside uterine cavity), molar pregnancy (disorganized proliferation of trophoblastic tissue), placenta previa (placenta attached to lower uterine segment), preterm birth (birth before 37 completed weeks of pregnancy), healthy term infant (birth after 37 completed weeks of pregnancy).

\section{RESULTS}

A total of 75 participants were included in the study. Mean age of study population was $29 \pm 8.0$, out of these 13 were primigravida and 62 were multigravida. The majority of participants presented at $8^{\text {th }}$ week of gestation. Other important variables of history, examination and ultrasound are elaborated in Table 1.

Table 1: Variable of history, examination and ultrasound findings.

\begin{tabular}{|c|c|c|}
\hline Variable & & $\mathbf{N}(\%)$ \\
\hline \multirow{2}{*}{ Previous miscarriage } & Present & $18(24)$ \\
\hline & Absent & $57(76)$ \\
\hline \multirow{2}{*}{$\begin{array}{l}\text { Evidence of intrauterine } \\
\text { pregnancy }\end{array}$} & Present & $10(13)$ \\
\hline & Absent & $65(86)$ \\
\hline \multirow{2}{*}{ Fetal cardiac activity } & Present & $47(62)$ \\
\hline & Absent & $28(37)$ \\
\hline \multirow{3}{*}{ Episodes of bleeding } & $01-3$ & $21(28)$ \\
\hline & $04-5$ & $31(41)$ \\
\hline & $>5$ & $23(30)$ \\
\hline
\end{tabular}

Out of 75 participants who presented with first trimester bleeding $40 \%$ ended up in miscarriage. $6 \%$ had ectopic, $2 \%$ had molar pregnancy, $4 \%$ had placenta previa, $6 \%$ had preterm birth and $40 \%$ had healthy infant at the end of pregnancy Table 2 .

Table 2: Frequencies of outcome variable.

\begin{tabular}{|ll|}
\hline Outcomes & $\mathbf{N}(\%)$ \\
\hline Miscarriage & $30(40)$ \\
\hline Ectopic pregnancy & $5(6.7)$ \\
\hline Molar pregnancy & $2(2.6)$ \\
\hline Placenta previa & $3(4)$ \\
\hline Preterm birth & $5(6.7)$ \\
\hline Healthy term infant & $30(40)$ \\
\hline
\end{tabular}

The significant factor in past history was history of miscarriage which was found in 18 participants. Out of these $18,14(77.7 \%)$ ended in miscarriage, $2(11.1 \%)$ had 
molar and only $2(11.1 \%)$ had healthy term infant. 57 participants had no previous history of miscarriage and out of them $28(49 \%)$ had healthy term infant, $3(5 \%)$ had placenta previa and $5(8 \%)$ had preterm birth (Table 3$)$.

Table 3: Relationship between past history of miscarriage and outcome.

\begin{tabular}{|l|l|l|}
\hline $\begin{array}{l}\text { Outcome } \\
\text { variable }\end{array}$ & $\begin{array}{l}\text { Past history of } \\
\text { miscarriage }\end{array}$ & $\begin{array}{l}\text { No past history } \\
\text { of miscarriage }\end{array}$ \\
\hline Miscarriage & 14 & 16 \\
\hline $\begin{array}{l}\text { Ectopic } \\
\text { pregnancy }\end{array}$ & - & 5 \\
\hline Molar pregnancy & 2 & - \\
\hline Placenta previa & - & 5 \\
\hline Preterm & - & 3 \\
\hline $\begin{array}{l}\text { Healthy term } \\
\text { infant }\end{array}$ & 2 & 28 \\
\hline
\end{tabular}

Individuals who had fetal cardiac activity at presentation had better outcomes then those who had not. Out of 47 participants with fetal cardiac activity 30 (63\%) had healthy term infant, $5(10 \%)$ had preterm birth, $3(6 \%)$ had placenta previa and only $9(19 \%)$ had miscarriage. While out of 28 individuals with no fetal cardiac activity $21(75 \%)$ had miscarriage, $5(17 \%)$ had ectopic and none had healthy term infant (Table 4).

Table 4: Relationship between cardiac flicker on ultrasound and outcome.

\begin{tabular}{|lll|}
\hline Outcome variable & $\begin{array}{l}\text { Cardiac flicker } \\
\text { present }\end{array}$ & $\begin{array}{l}\text { Cardiac } \\
\text { flicker absent }\end{array}$ \\
\hline Miscarriage & 9 & 21 \\
\hline Ectopic pregnancy & - & 5 \\
\hline Molar pregnancy & - & 2 \\
\hline Placenta previa & 5 & - \\
\hline Preterm & 3 & - \\
\hline $\begin{array}{l}\text { Healthy term } \\
\text { infant }\end{array}$ & 30 & - \\
\hline
\end{tabular}

Table 5: Relationship between severity of bleeding and outcome.

\begin{tabular}{|llll|}
\hline $\begin{array}{l}\text { Outcome } \\
\text { variable }\end{array}$ & $\begin{array}{l}\mathbf{1 - 3} \\
\text { bleeding } \\
\text { episode }\end{array}$ & $\begin{array}{l}\mathbf{3 - 5} \\
\text { bleeding } \\
\text { episodes }\end{array}$ & $\begin{array}{l}\mathbf{> 5} \\
\text { bleeding } \\
\text { episodes }\end{array}$ \\
\hline Miscarriage & 9 & 11 & 10 \\
\hline $\begin{array}{l}\text { Ectopic } \\
\text { pregnancy }\end{array}$ & - & 5 & - \\
\hline Molar pregnancy & - & 2 & - \\
\hline Placenta previa & - & - & 5 \\
\hline Preterm & - & 3 & - \\
\hline $\begin{array}{l}\text { Healthy term } \\
\text { infant }\end{array}$ & 12 & 10 & 8 \\
\hline
\end{tabular}

Individuals with less bleeding episodes i.e. 1-3 were 21, out of them $9(42 \%)$ had miscarriage and $12(57 \%)$ had healthy term infants. Out of 31 individuals with 4-5 bleeding episodes $11(35 \%)$ had miscarriage, $5(16 \%)$ had ectopic, $2(6 \%)$ had molar and $14(45 \%)$ had healthy term infant. Out of 23 individuals with more than 5 bleeding episodes $10(43 \%)$ had miscarriage, $8(34 \%)$ has healthy term infants and $5(2 \%)$ had preterm birth (Table 5).

\section{DISCUSSION}

First trimester vaginal bleeding is a common presenting complain not only at primary healthcare setting but also at the emergency department of a tertiary care hospital. This condition caries multiple etiologies behind it which impact the health of not only mother but also the newborn. Clinical history, examination and ultrasound scan plays an important role in diagnosis and to formulate a prognosis. This study takes many relevant points of history, examination and ultrasound examination into consideration.

The mean age of our study population was $29 \pm 8$, the mean age of gestation at presentation was 8 weeks and majority of participants were multigravida, this data is almost similar to study done by riaz ahmed and farah naz in Gujrat, Pakistan, but the data is different from Nigerian study in which the gestational age at presentation was around 12 weeks. ${ }^{7}$ This difference could be due to geographical and racial variation between the two populations. $^{8}$

Although first trimester bleeding is associated with adverse pregnancy outcome, $40 \%$ of study population had healthy term infants at the end of their pregnancies, the same percentage i.e. $40 \%$ ended in miscarriage and the rest $10 \%$ also had bad outcomes (6.7\% ectopic, $2.6 \%$ molar, $4 \%$ preterm, and $6.7 \%$ placenta previa), these results are quite similar to an Indian study where $50 \%$ of study participants with first trimester bleeding had healthy infants at the end of their pregnancies, $45.5 \%$ had miscarriage, $1 \%$ had molar pregnancy and $8 \%$ had ectopic pregnancy. ${ }^{9}$ Study done in Turkey also strengthens the fact that early pregnancy bleeding is associated with adverse outcomes and states that bleeding in early pregnancy makes the index pregnancy high risk. $^{10}$

Previous history of miscarriage has strong relation with adverse pregnancy outcome in current pregnancy especially if the index pregnancy is complicated by early pregnancy bleeding. Our study also establishes this relationship where $24 \%$ of participants had history of miscarriage in previous pregnancy and out of them $77 \%$ ended in miscarriage and only $11 \%$ had healthy infants. The study done by faswila et al also shows that history of miscarriage in previous pregnancy also increases the risk of averse pregnancy outcomes like PROM and IUD apart from miscarriage. ${ }^{11}$

Ultrasound scan at presentation to healthcare facility plays a very important role in making diagnosis in 
patients with early pregnancy bleeding. ${ }^{12,13}$ Our study also shows good maternal and fetal outcomes in patients who had fetal cardiac activity present at the time of first presentation to the hospital.

Amount and frequency of bleeding has strong relation with pregnancy outcomes especially if the bleeding is associated with pain. The less the amount of bleeding the less the chance of losing the pregnancy while heavy and repeated bleeding not only increases the risk of miscarriage but recurrent bleeding also makes the pregnancy high risk even after reaching the age of viability. In Ara et al most of the women with heavy bleeding had abortion while rate of continuation of pregnancy was higher with spotting. ${ }^{9}$ In Kamble et al, $96.44 \%$ women with heavy bleeding had abortion and $3.55 \%$ continued their pregnancy. In women with spotting, $81.26 \%$ had abortion and $18.74 \%$ continued their pregnancy. ${ }^{14}$ Based on this study $43 \%$ of those who had more than 5 episodes of bleeding ended up in miscarriage and only $34 \%$ had healthy term infants.

\section{Strengths}

The strength of this study is its prospective design, consecutive recruitment, and well characterized patient's cohort.

\section{Limitations}

This study is conducted at tertiary care hospital where the high risk cases are brought and many females with small amount of PV bleeding in pregnancy go unnoticed as they attend primary care settings.

\section{CONCLUSION}

Bleeding in pregnancy is a red flag sign and needs to be addressed with wise approach to have optimal possible maternal and fetal outcomes. Timely and appropriate management and counselling will help in reducing complication as well as the anxiety associated with the condition. This study also establishes the relationship between adverse pregnancy outcomes and first trimester bleeding especially if associated with heavy and recurrent bleeding. However a large multicentre study on this topic in our region is required.

\section{ACKNOWLEDGMENTS}

Authors would like to thank the doctors and staff of emergency department and ultrasound department who helped in identifying these cases and also appreciate patient's compliance to follow up.

Funding: No funding sources Conflict of interest: None declared Ethical approval: Not required

\section{REFERENCES}

1. Evrenos AN, Gungor AN, Gulerman C, Cosar E. Obstetric outcomes of patients with abortus imminens in the first trimester. Arch Gynecol Obst. 2014;289(3):499-504.

2. Lykke JA, Dideriksen KL, Lidegaard $\varnothing$, Roos J. First-trimester vaginal bleeding and complications later in pregnancy. Obst Gynecol. 2010;115(5):93544.

3. Saraswat L, Bhattacharya S, Maheshwari A, Bhattacharya S. Maternal and perinatal outcome in women with threatened miscarriage in the first trimester: a systematic review. Int J Obst Gynaecol. 2010;117(3):245-57.

4. National Institute for Health and Care Excellence (Great Britain). Ectopic pregnancy and miscarriage: diagnosis and initial management. National Institute for Health and Care Excellence. 2019. Available at https://www.nice.org.uk/guidance/ng126/resources/e ctopic-pregnancy-and-miscarriage-diagnosis-andinitial-management-pdf-66141662244037. Accessed on 12 September 2020.

5. Tidy J, Seckl M, Hancock BW. Management of gestational trophoblastic disease green-top guideline. Int J Obst Gynaecol. 2020;3:78-98.

6. Gollapalli S, Gunda J. Pregnancy outcome in women with first-trimester bleeding per vaginum. Int $\mathrm{J}$ Clin Obstet Gynaecol. 2020;4(2):321-3.

7. Zhu CS, Tan TC, Chen HY, Malhotra R, Allen JC, Østbye T. Threatened miscarriage and depressive and anxiety symptoms among women and partners in early pregnancy. J Affective Dis. 2018;237:1-9.

8. Ahmad R, Aziz FN. Bleeding in early pregnancy; various ways of presentation and outcome. Professional Med J. 2017;24(4):23-9.

9. Olugbenga AO. Pregnancy outcome in women with early pregnancy bleeding in a tertiary health care facility in Southwestern, Nigeria. J Mahatma Gandhi Institute Med Sci. 2019;24(2):87.

10. Ara J, Dahiya K, Dahiya A. Study of maternal and perinatal outcome in women with first trimester vaginal bleeding. Int $\mathrm{J}$ Healthcare Biomed Res. 2018;6(02):122-30.

11. Yakıştıran B, Yüce T, Söylemez F. First trimester bleeding and pregnancy outcomes: case-control study. Int J Women's Health Reprod Sci. 2016;4(1):4-7.

12. Faswila M, Ramya NR. Pregnancy outcome in patient who had first trimester bleeding in previous pregnancy: a prospective study. Int $\mathbf{J}$ Reprod Contracep Obst Gynecol. 2016;9(4):1560.

13. Varner C, Balaban D, Borgundvaag B, McLeod S, Carver S. Fetal outcomes following emergency department point-of-care ultrasound for vaginal bleeding in early pregnancy. Canadian Family Physician. 2016;62(7):572-8.

14. Sinha A, Amit K. Assessment of vaginal bleeding in first trimester of pregnancy by comparative study of 
clinical and ultrasonographic evaluation. Int J Med Biomed Studies. 2019;3(12):43-9.

15. Kamble PD, Bava A, Shukla M, Nandanvar YS. First trimester bleeding and pregnancy outcome. Int $\mathrm{J}$ Reprod Contracept Obstet Gynecol. 2017;6:1484-7.
Cite this article as: Moon A, Shabbir S. Pregnancy outcome in women presenting with per vaginal bleeding in first trimester of pregnancy. Int J Reprod Contracept Obstet Gynecol 2021;10:439-43. 